\title{
Partial replacement of soybean meal by peanut and sesame seed meals in practical diets for rainbow trout, oncorhynchus mykiss
}

\begin{abstract}
This study was conducted to evaluate the partial replacement of soybean meal by sesame seed and peanut meals in practical diets for rainbow trout (Oncorhynchus mykiss). Four isonitrogenous ( $44 \%$ protein) and isolipidic (19\% lipid) diets were formulated. The trial diets were prepared to include $10 \%$ sesame seed meal $\left(\mathrm{S}_{10}\right), 10 \%$ peanut meal $\left(\mathrm{P}_{10}\right), 5 \%$ sesame seed meal $+5 \%$ peanut meal mix $\left(\mathrm{SP}_{10}\right)$ and a control $(\mathrm{C})$ with no replacement of soybean meal. There were four dietary treatments, with three replicates for each treatment. The fish (initial average weight; $79.86 \pm 0.14 \mathrm{~g}$ ) were hand-fed twice a day to apparent satiety under a natural light regime for 65 days. At the end of experiment, the best growth was determined in $\mathrm{SP}_{10}$ group $(\mathrm{p}<0.05)$. The growth performance of $\mathrm{S}_{10}$ and $\mathrm{P}_{10}$ groups was significantly lower than control and $\mathrm{SP}_{10}$ groups $(\mathrm{p}<0.05)$. The hepatosomatic index (HSI) and viscerosomatic index (VSI) values were not affected from the protein sources in the diets $(\mathrm{p}>0.05)$. Comparing to the initial sample, the moisture, protein, lipid and ash contents in the body composition of the fish increased in all experimental groups and were not significantly differed among the groups $(\mathrm{p}>0.05)$. In the crude protein digestibility was no differences in among groups ( $>0.05$ ), but the highest apparent protein digestibility coefficients were determined for $\mathrm{C}(91.26 \%)$ and $\mathrm{SP}_{10}(91.93 \%)$ groups. The present results demonstrated that $10 \%$ sesame seed meal and peanut meal could be used in diets of rainbow trout without any negative effects on growth. The results showed that using these protein sources together may provide better results rather than using them alone.
\end{abstract}

Keywords: Feed formulation, Proximate composition, Sesame seed, Peanut, Alternative protein source
Volume 6 Issue I - 2017

Seval Dernekba i, Ismihan KARAY CEL

Department of Aquaculture, University of Sinop, Turkey

Correspondence: Seval Dernekba?i, Department of Aquaculture, Faculty of Aquaculture and Fisheries, University of Sinop, Turkey, Tel 90368287 6254,

Email sevalyaman@hotmail.com

Received: July 08, 2017 | Published: July 26, 2017
Abbreviations: $\mathrm{S}_{10}, 10 \%$ Sesame Seed Meal; $\mathrm{P}_{10}, 10 \%$ Peanut Meal; $\mathrm{SP}_{10}, 5 \%$ Sesame Seed Meal $+5 \%$ Peanut Meal Mix; C, Control; ANFs, Anti-Nutritional Factors; ADC, The Apparent Digestibility Coefficient; ADCprotein, Apparent Protein Digestibility Values; FBW, Final Body Weight; WG, Weight Gain; FCR, Feed Conversion Rate; SGR, Specific Growth Rate; PER, Protein Efficiency Rate; VSI, Viscerosomatic Index; HSI, Hepatosomatic Index; Cr2O3 , Chromic Oxide; EAA, Essential Amino Acids; NEAA, Non-Essential Amino Acids.

\section{Introduction}

The aquaculture sector is developing more effectively than other food production sectors. However, economic factors such as feed cost are inhibiting development. Fish meal has resulted in its wide inclusion as the main protein source in diets for fish culture, because of its high protein content, palatability and well balanced amino acid profile. Nevertheless, in the near future, the production of such protein will not be enough to cover the increasing demand of this ingredient for animal diets. ${ }^{1,2}$ In recent research, it has been shown that many plant protein sources has potential protein source in fish feed and was utilized successfully in many experimental aquaculture diets. ${ }^{3}$ Therefore, concerning the more common usage and usability of the fish meal for fish feed is restricted by increasing demand for human consumption and by other animal feed industries. ${ }^{4}$ This phenomenon has support the requirement search for cheaper alternative protein source for the improving of low-cost feed that can replace traditional feedstuff without reducing the nutritional quality of the diets.

Soybean meal has high protein content, better amino acid composition and the best protein quality among other plant protein feedstuffs used in fish feeds. ${ }^{6}$ Thus, it is among the most preferred plant protein sources in the diet poultry and swine all over the world ${ }^{7}$ and currently the most commonly used plant protein source in fish feed. ${ }^{8}$ But like fish meal, the soybean meal is also expensive ${ }^{9}$ and the usage of soybean meal increases greatly feed costs. More work is required to detect alternative protein-rich feed ingredients suitable for cultured fish. ${ }^{10}$

Due to increases in cost and global demand of fish meal and soybean meal, the usage of other vegetable proteins in fish diets has become more widespread in recent years. ${ }^{3}$ Therefore, the use of less expensive and easily available plant protein sources are needed to reduce dependence on fish meal and soybean meal as the fundamental protein sources for aquatic animal diets without reducing the nutritional quality of feeds. ${ }^{4,1}$

Despite the large number of studies carried out in this subject, in general made studies are based on the use of vegetable protein sources partially or totally replacement of fish meal. Therefore, the objective of the present study was to evaluate the effects of partial replacement of soybean meal by sesame seed and peanut meal in diets for rainbow trout (Oncorhynchus mykiss) on the growth performance, feed utilization and body composition.

\section{Materials and methods}

\section{Fish maintenance and experimental planned}

The experiment was conducted at an indoor facility of the Faculty of Fisheries, University of Sinop (Sinop/Turkey). Experimental fish were obtained from a commercial trout farm (Kuzey Fish Farm Inc.) in Samsun/Turkey and acclimated in three $1000 \mathrm{~L}$ rectangle fiberglass 
tanks for two weeks before the experiment. During the acclimation, the fish were fed with a commercial trout feed (Black Sea Feed) two times a day by hand according to apparent satiation. After acclimatization, fish (initial mean weight of $79.86 \pm 0.14 \mathrm{~g}$ ) were fasted for a day, individually weighted to the nearest $1 \mathrm{~g}$, and randomly distributed twelve circular fiberglass tanks (water volume of $300 \mathrm{~L}$ ) at 13 fish per tank with three replicates. Water flow rate was adjusted to $4 \mathrm{~L}$ min-1 and additional aeration was supplied via air stone. The water quality parameters were monitored on weekly basis and average temperature, dissolved oxygen and $\mathrm{pH}$ were $15.92 \pm 0.09^{\circ} \mathrm{C}, 6.77 \pm 0.77 \mathrm{mg} / \mathrm{L}$ and 8.15. At the beginning (20 fish) and at the end ( 5 fish from each tank) of the study, the fish were killed with overdose anaesthetics (clove oil). Fillet samples taken from the lower part of dorsal fin were removed for homogenization and analyzed.

\section{Diet formulation and preparation}

Feed ingredients were supplied by a domestic fish feed producer (Sibal Inc., Black Sea Feed, Sinop /Turkey). Sesame seed meal and peanut meal were obtained from commercial firms (Filiz Confectionery \& Food Inc., Samsun/Turkey; Başpınar Peanuts, Crops and Transport Inc., Osmaniye/Turkey, respectively). Sesame seed meal and peanut meal in the experiment feeds was prepared by chancing with $10 \%$ of soybean meal. Nutrient composition of the feed ingredients was shown in Table 1. Four experimental diets (a control no containing peanut and sesame seed meal $(\mathrm{C}), 10 \%$ sesame seed meal $\left(\mathrm{S}_{10}\right), 10 \%$ peanut meal $\left(\mathrm{P}_{10}\right)$ and $5 \%$ sesame seed meal $+5 \%$ peanut meal mix $\left(\mathrm{SP}_{10}\right)$ ] were formulated (Table 2). Amino acid composition of the experimental diets was shown in Table 3 . Chromic oxide $(\mathrm{Cr} 2 \mathrm{O} 3)$ was added into the diets as a marker at a concentration of $0.5 \%$ to detect the apparent digestibility of the diets. Feed ingredients were fully mixed, homogenized, moistened by the addition of $35 \%$ water and pelleted $(4.0 \mathrm{~mm})$ in a mincing machine. The pellets were dried at $50^{\circ} \mathrm{C}$ for 8 $\mathrm{h}$, cut into pieces almost $5 \mathrm{~mm}$ in length. Amino acid composition of experimental diet and muscles were analysed in triplicate following acid hydrolysis using pressure liquid chromatography (Agilent 1100 Series HPLC System) on a dry weight basis. ${ }^{12}$ All feeds were stored $-40^{\circ} \mathrm{C}$ in plastic bags until the feeding.

\section{Feeding and faecal collection}

The study was conducted in triplicates in a randomly assigned tanks. During experimental period, fish in all groups were fed by hand to satiation twice a day (at 09:00 am and 16:00 pm) under a natural light regime for 65 days. Fish were fed slowly and carefully so that no uneaten feed stayed on the tank bottoms. The tanks were completely cleaned after each feeding. Before the trial, the fish were subjected to a 1-week adaptation period. Faecal samples were gathered by slow siphoning with an $8 \mathrm{~mm}$ plastic tube after $1 \mathrm{~h}$ from each feeding and frozen quickly at $-40^{\circ} \mathrm{C}$ until analysis.

\section{Proximate composition}

The proximate composition of feed ingredients, experimental diets, fish samples and faeces were analyzed as follows: dry matter after drying in an oven at $105^{\circ} \mathrm{C}$ until constant weight; crude protein ( $\mathrm{N}$ x 6.25) by Kjeldahl method after acid digestion; crude lipid by petroleum ether extraction in a Soxhlet apparatus and crude ash by incineration in a muffle furnace at $550^{\circ} \mathrm{C}$ for 6 hours by the standard methods of AOAC. ${ }^{13}$ Chromium oxide in the diet and faeces was detected spectophotometrically according to Petry and Rapp. ${ }^{14}$ Apparent protein digestibility coefficients were calculated as ADC $(\%)=100-[100(\% \mathrm{Cr} 2 \mathrm{O} 3$ in diet $/ \% \mathrm{Cr} 2 \mathrm{O} 3$ in faeces $) \times(\%$ nutrient in faeces $/ \%$ nutrient in diet)] as per Degani. ${ }^{15}$ Gross energy of the diets was forecasted supposing $23.6 \mathrm{~kJ} / \mathrm{g}$ protein, $39.5 \mathrm{~kJ} / \mathrm{g}$ lipid and 17 $\mathrm{kJ} / \mathrm{g}$ nitrogen free extracts. All analyses were done in triplicate.

\section{Calculations}

The following calculations were made: Feed conversion rate $(\mathrm{FCR})=$ total feed intake/weight gain Specific growth rate $(\mathrm{SGR}) \quad(\%$ day- 1$)=[(\ln$ initial weight- $\ln$ final weight)/days] x 100 Protein efficiency rate $(\mathrm{PER})=$ wet weight gain/protein fed Hepatosomatic index (HSI) $(\%)=($ liver weight / body weight $) \times 100$ Viscerasomatic index $(\mathrm{VSI})(\%)=($ viscera weight/body weight $) \times 100$

\section{Statistical analysis}

Statistical analysis included one-way analysis of variance (ANOVA) and Tukey's multiple significant difference tests using the software program (Minitab 13.0 for Windows). Arcsine square root transformations of percentage data were conducted for homogeneity of variances before statistical analysis. A p-value $<0.05$ was considered as significant.

\section{Results}

\section{Biochemical and amino acid compositions of experimental diets}

Nutrient composition of the feed ingredients was presented in Table 1. The chemical and amino acid composition of experimental diets were shown in Table 2 and Table 3, respectively. The best total essential amino acid composition of the experimental diets was determined in $\mathrm{SP}_{10}$ diet. The highest lysine amount was also seen in $\mathrm{SP}_{10}$ diet. The methionine amounts of the $\mathrm{C}$ and $\mathrm{SP}_{10}$ diets were higher than the $\mathrm{S}_{10}$ and $\mathrm{P}_{10}$ diets.

\section{Growth performance}

The fish accepted all the experimental diets and no mortalities occurred during the experiment. The best final body weight (FBW), weight gain (WG) feed conversion rate (FCR), specific growth rate (SGR) and protein efficiency rate (PER) were determined in $\mathrm{SP}_{10}$ and control $(C)$ groups, respectively $(\mathrm{p}<0.05)$. The viscerosomatic index (VSI) and hepatosomatic index (HSI) values were not affected from the different plant protein sources in the diets $(p>0.05)$. The highest HSI and VSI were in $\mathrm{S}_{10}$ group (Table 4).

\section{Digestibility}

Apparent protein digestibility values (ADCprotein) was given in Table 5. ADCprotein values were similar in $\mathrm{C}, \mathrm{S}_{10}, \mathrm{P}_{10}$ and $\mathrm{SP}_{10}$ groups. There were no statistically significant differences in the digestibility of protein among the experimental groups $(\mathrm{p}>0.05)$.

\section{Biochemical and amino acid composition of muscle}

There was significant differences between the initial and final body composition of fish in all experimental groups in terms of moisture, protein, lipid and ash contents (Table 6) $(\mathrm{p}<0.05)$. There was no statistically significant differences among final body composition of fish in all experimental groups ( $p>0.05$ ). Although protein contents of fish in $\mathrm{C}$ and $\mathrm{SP}_{10}$ groups was higher than fish in $\mathrm{S}_{10}$ and $\mathrm{P}_{10}$ groups, there was no significant difference between them $(p>0.05)$. The amino acid composition of muscle from rainbow trout fed experimental diets was shown in Table 7. 
Table I Nutrient composition of the feed ingredients (as \% dry matter)

\begin{tabular}{lllll}
\hline & Parameter & & & \\
\hline Feed Ingredients & Moisture & Crude protein & Crude lipid & Crude ash \\
Fish meal & 9.20 & 73.12 & 13.7 & 9.75 \\
Soybean meal & 11.58 & 46 & 3.21 & 5.82 \\
Sesame seed meal & 9.40 & 21 & 36 & 8.90 \\
Peanut meal & 5.7 & 30.6 & 10.35 & 7.52 \\
Corn gluten & 9.86 & 58.5 & 1.93 & 2.89 \\
\hline
\end{tabular}

Table 2 Formulation and chemical compositions of the control and experimental diets

\begin{tabular}{|c|c|c|c|c|}
\hline & \multicolumn{4}{|c|}{ Experimental Diets } \\
\hline & C & $\mathbf{S}_{10}$ & $\mathbf{P}_{10}$ & $\mathbf{S P}_{10}$ \\
\hline \multicolumn{5}{|l|}{ Ingredients ( g kg-1) $^{-1}$} \\
\hline Fish meal & 331.5 & 331.5 & 331.5 & 331.5 \\
\hline Extracted soybean meal & 250 & 190 & 190 & 190 \\
\hline Wheat flour & 130 & 130 & 110 & 120 \\
\hline Corn gluten & 150 & 150 & 150 & 150 \\
\hline Sesame seed meal & 0 & 100 & 0 & 50 \\
\hline Peanut meal & 0 & 0 & 100 & 50 \\
\hline Fish oil & 130 & 90 & 110 & 100 \\
\hline Vitamin premix $(*)$ & 2 & 2 & 2 & 2 \\
\hline Mineral premix $(*)$ & 1.5 & 1.5 & 1.5 & 1.5 \\
\hline Chromic oxide (Cr2O3) & 5 & 5 & 5 & 5 \\
\hline \multicolumn{5}{|c|}{ Proximate Composition (\%) } \\
\hline Dry matter & 95.71 & 94.74 & 94.64 & 94.81 \\
\hline Protein & 44.28 & 43.93 & 44.45 & 44.45 \\
\hline Lipid & 19.1 & 19.6 & 19.3 & 19.2 \\
\hline Ash & 6.35 & 7.34 & 6.96 & 7.03 \\
\hline NFE+Crude fiber' & 25.98 & 23.97 & 23.93 & 24.13 \\
\hline Gross energy $\left(\mathrm{kJ} \mathrm{g} \mathrm{g}^{-1}\right)^{2}$ & 22.41 & 22.17 & 22.18 & 22.14 \\
\hline
\end{tabular}

*Vitamin-mineral premix (mcg/kg premix): vitamin A, $210000 \mathrm{IU}$;Vitamin $\mathrm{D}_{3}, 35000 \mathrm{IU}$; vitamin E, 7000 mcg; vitamin $\mathrm{K}_{3}, 322$ mcg; vitamin $\mathrm{B}_{1}, 588 \mathrm{mcg}$; vitamin $\mathrm{B}_{2}$, 252 mcg; vitamin B, 294 mg; vitamin B, 826 mcg; niacin, I 400 mcg; biotin, 7583 mcg; I 82 mcg folic acid, pantothenic acid, I 722 mcg; inositol, I 7220 mcg; vitamin C, $933.31 \mathrm{mcg} ; \mathrm{Ca}, \mathrm{I} 14 \mathrm{Hmcg}$.

'NFE+Crude fiber=100-(\%protein+ \%lipid+ \%ash+ \%moisture)

${ }^{2}$ Gross energy is calculated according to $23.6 \mathrm{~kJ} \mathrm{~g}^{-1}$ protein, $39.5 \mathrm{~kJ} \mathrm{~g}^{-1}$ lipid and $17 \mathrm{~kJ} \mathrm{~g}^{-1} \mathrm{NFE}$

Table 3 Amino acid composition of the experimental diets ( $\mathrm{g} / \mathrm{l00} \mathrm{g}$ dry weight)

\begin{tabular}{|c|c|c|c|c|}
\hline & \multicolumn{4}{|c|}{ Diet Groups } \\
\hline & C & $\mathbf{S}_{10}$ & $\mathbf{P}_{10}$ & $\mathbf{S P}_{10}$ \\
\hline \multicolumn{5}{|c|}{ Essential Amino Acids (EAA, g/l00g) } \\
\hline Histidine & 1.89 & 1.40 & 2.41 & 2.29 \\
\hline Isoleucine & 1.84 & 1.53 & 1.41 & 1.73 \\
\hline Leucine & 4.35 & 3.64 & 3.13 & 3.95 \\
\hline Lysine & 1.00 & 1.12 & 0.88 & 1.85 \\
\hline Methionine & 0.79 & 0.44 & 0.60 & 0.72 \\
\hline Phenylalanine & 2.24 & 1.82 & 1.70 & 2.01 \\
\hline Threonine & 1.96 & 1.98 & 2.85 & 3.00 \\
\hline Valine & 1.23 & 0.94 & 1.15 & 0.98 \\
\hline Total & 15.3 & 12.87 & 14.13 & 16.53 \\
\hline \multicolumn{5}{|c|}{ Non-essential amino acids(NEAA, g/l00g) } \\
\hline Alanine & 3.22 & 2.33 & 3.45 & 3.23 \\
\hline Aspartic acid & 5.30 & 6.90 & 5.16 & 4.53 \\
\hline Glutamic acid & 9.51 & 11.07 & 7.58 & 7.90 \\
\hline Glycine & 1.63 & 1.04 & 2.88 & 2.08 \\
\hline Serine & 2.96 & 1.98 & 4.18 & 2.52 \\
\hline Tyrosine & 1.90 & 1.97 & 1.78 & I.7। \\
\hline Total & 24.52 & 25.29 & 25.03 & 21.97 \\
\hline
\end{tabular}

Citation: Dernekbasi S, Karayucel I. Partial replacement of soybean meal by peanut and sesame seed meals in practical diets for rainbow trout, oncorhynchus mykiss. J Aquac Mar Biol. 20 I7;6(I):I I-I2. DOI: I0.15406/jamb.20I7.05.00 I 46 
Table 4 Growth performance, feed efficiency and other body parameters in rainbow trout fed the experimental diets

\begin{tabular}{lllll}
\hline Parameters & $\mathbf{C}$ & $\mathbf{S}_{10}$ & $\mathbf{P}_{10}$ & $\mathbf{S P}_{10}$ \\
\hline Initial body weight $(\mathrm{g})$ & $79.79 \pm 0.33$ & $79.87 \pm 0.40$ & $79.54 \pm 0.63$ & $80.23 \pm 0.49$ \\
Final body weight $(\mathrm{g})$ & $200.72 \pm 7.97^{\mathrm{a}}$ & $184.41 \pm 3.55^{\mathrm{b}}$ & $183.94 \pm 16.42^{\mathrm{b}}$ & $213.54 \pm 6.3 \mathrm{I}^{\mathrm{c}}$ \\
Weight gain (g) & $120.92 \pm 8.24^{\mathrm{a}}$ & $104.54 \pm 3.17^{\mathrm{b}}$ & $104.40 \pm 16.87^{\mathrm{b}}$ & $133.31 \pm 6.49^{\mathrm{c}}$ \\
FCR & $1.16 \pm 0.02^{\mathrm{a}}$ & $1.30 \pm 0.04^{\mathrm{b}}$ & $1.23 \pm 0.14^{\mathrm{b}}$ & $1.10 \pm 0.04 \mathrm{a}$ \\
SGR $\left(\%\right.$ dayg $\left.^{-1}\right)$ & $1.64 \pm 0.08^{\mathrm{a}}$ & $1.49 \pm 0.03^{\mathrm{b}}$ & $1.48 \pm 0.17^{\mathrm{b}}$ & $1.75 \pm 0.06^{\mathrm{c}}$ \\
PER & $2.73 \pm 0.19^{\mathrm{a}}$ & $2.38 \pm 0.07^{\mathrm{b}}$ & $2.36 \pm 0.38^{\mathrm{b}}$ & $3.01 \pm 0.14^{\mathrm{c}}$ \\
HSI (\%) & $1.61 \pm 0.10$ & $1.66 \pm 0.16$ & $1.68 \pm 0.10$ & $1.56 \pm 0.12$ \\
VSI (\%) & $10.45 \pm 0.24$ & $10.67 \pm 0.45$ & $11.20 \pm 0.30$ & $10.74 \pm 0.20$ \\
\hline
\end{tabular}

Different superscripts within the row denote significant differences.

Table 5 Apparent digestibility coefficients (ADCs) of dry matter and protein in diets

\begin{tabular}{|c|c|c|c|c|}
\hline \multirow{2}{*}{ Parameters } & \multicolumn{3}{|c|}{ Diet groups } & \multirow[b]{2}{*}{$\mathbf{S P}_{10}$} \\
\hline & C & $\mathbf{S}_{10}$ & $\mathbf{P}_{10}$ & \\
\hline Dry matter (\%) & $77.12 \pm 2.38^{\mathrm{a}}$ & $72.38 \pm 3.64^{b}$ & $73.84 \pm 2.40^{b}$ & $77.92 \pm 0.79^{a}$ \\
\hline Crude Protein (\%) & $91.29 \pm 0.80^{\mathrm{a}}$ & $89.76 \pm 1.50^{\mathrm{a}}$ & $89.97 \pm 0.94^{\mathrm{a}}$ & $91.93 \pm 0.24^{a}$ \\
\hline
\end{tabular}

Table 6 Chemical composition of muscle of rainbow trout fed the experimental diets (\% wet weight)

\begin{tabular}{llllll}
\hline Parameters & Initial & C & S $_{10}$ & $\mathbf{P}_{10}$ & $\mathbf{S P}_{10}$ \\
\hline Moisture (\%) & $78.09 \pm 0.29^{\mathrm{a}}$ & $73.58 \pm 0.4 \mathrm{I}^{\mathrm{b}}$ & $73.75 \pm 0.07^{\mathrm{b}}$ & $74.6 \mathrm{I} \pm 0.25^{\mathrm{b}}$ & $74.28 \pm 0.13^{\mathrm{b}}$ \\
Protein (\%) & $18.24 \pm 0.0 \mathrm{I}^{\mathrm{a}}$ & $21.39 \pm 0.05^{\mathrm{b}}$ & $20.49 \pm 0.03^{\mathrm{b}}$ & $20.49 \pm 0.04^{\mathrm{b}}$ & $21.19 \pm 0.46^{\mathrm{b}}$ \\
Lipid (\%) & $3.39 \pm 0.0 \mathrm{I}^{\mathrm{a}}$ & $4.70 \pm 0.28^{\mathrm{b}}$ & $4.46 \pm 0.33^{\mathrm{b}}$ & $4.04 \pm 0.03^{\mathrm{b}}$ & $4.5 \mathrm{I} \pm 0.22^{\mathrm{b}}$ \\
Ash (\%) & $1.36 \pm 0.0 \mathrm{I}^{\mathrm{a}}$ & $1.73 \pm 0.04^{\mathrm{b}}$ & $1.68 \pm 0.07^{\mathrm{b}}$ & $1.68 \pm 0.02^{\mathrm{b}}$ & $1.73 \pm 0.04^{\mathrm{b}}$ \\
\hline
\end{tabular}

Different superscripts within the row denote significant differences.

Table 7 Amino acid composition of muscle from rainbow trout fed experimental diets ( $g / 100 g$ dry weight)

\begin{tabular}{|c|c|c|c|c|c|}
\hline & \multicolumn{5}{|c|}{ Diet Groups } \\
\hline & Initial & C & $\mathbf{S}_{10}$ & $\mathbf{P}_{10}$ & $\mathbf{S P}_{10}$ \\
\hline \multicolumn{6}{|c|}{ Essential amino acids (EAA, g/l00g) } \\
\hline Histidine & 2.09 & 2.31 & 2.15 & 2.58 & 2.63 \\
\hline Isoleucine & 3.54 & 3.80 & 3.63 & $3.4 I$ & 3.86 \\
\hline Leucine & 7.65 & 7.25 & 7.15 & 7.10 & 7.62 \\
\hline Lysine & 3.55 & 2.93 & 5.12 & 5.85 & 2.74 \\
\hline Methionine & 1.73 & 1.99 & 2.35 & 1.37 & 2.01 \\
\hline Phenylalanine & 3.43 & 3.70 & 3.17 & 3.36 & 3.82 \\
\hline Threonine & 6.50 & 4.59 & $4.4 I$ & 6.03 & 6.30 \\
\hline Valine & 2.73 & 2.62 & 2.73 & 1.92 & 3.24 \\
\hline Total & 31.22 & 29.19 & 30.71 & 31.62 & 32.22 \\
\hline \multicolumn{6}{|c|}{ Non-essential amino acids(NEAA, g/l00g) } \\
\hline Alanine & 6.64 & 5.32 & $5.4 I$ & 5.79 & 6.53 \\
\hline Aspartic acid & 11.18 & 11.67 & 13.02 & 11.55 & 11.07 \\
\hline Glutamic acid & 14.78 & 13.70 & $|3.4|$ & 13.15 & 13.07 \\
\hline Glycine & 3.69 & 3.01 & 2.49 & 3.90 & 3.05 \\
\hline Serine & 4.05 & 3.69 & 3.75 & 3.71 & 3.97 \\
\hline Tyrosine & 3.10 & 3.33 & 3.04 & 2.10 & 3.19 \\
\hline Total & 43.44 & 40.72 & 41.12 & 40.20 & 40.88 \\
\hline
\end{tabular}

\section{Discussion}

Although a significant amount of research was conducted on the replacement of fish meal with soybean meal or other plant meals as a protein source in feeds for rainbow trout, this research was regulated on the replacement of soybean meal by sesame seed meal and peanut meal in rainbow trout diet. The results of the present study indicated that sesame seed meal, peanut meal and sesame seed+peanut meals mix could be united in the diets of rainbow trout at a level of $10 \%$ as a replacer for soybean meal, without having any significant negative effect on growth or feed utilization.
It is reported that inclusion of higher levels of vegetable ingredients in salmonids diets has adverse effect on fish performance. ${ }^{16,17,18}$ Plant protein meals contain anti-nutritional factors (ANFs) and these cause reduce in growth performance and feed efficiency, ${ }^{19}$ and affect digestive enzyme activity and digestion/absorption capacity of animal. ${ }^{20}$ In the present study, reduction in growth and high feed conversion ratios were observed in fish of $\mathrm{S}_{10}$ and $\mathrm{P}_{10}$ groups. This reduction in the growth could be related, not only to dietary amino acid profile, but also to the presence of ANFs. Additionally, it is probably that the lower weight gain observed in the fish of $\mathrm{S}_{10}$ and $\mathrm{P}_{10}$ groups may have been resulted from lower consumption of those diets. This observation agrees with 
the findings of Jimoh and Aroyehun 5 for African catfish (Clarias gariepinus) fed sesame seed meal-based diet. Davies et al. ${ }^{21}$ declared that high participation levels of some oilseed meals resulted in poor growth and feed utilization by Nile tilapia (Oreochromis niloticus). Also, in the current study, comparing with the control, the best growth and FCR were obtained from $\mathrm{SP}_{10}$ group. At the same time, the highest SGR and PER were also observed in $\mathrm{SP}_{10}$ group.

HSI is an index that is used to investigate the effects of feeding on the liver, which is a key organ for metabolism and the standard HSI value for Osteichthyes is $1-2 \%{ }^{22}$ In this study, fish fed different diets did not show any significant differences in HSI which agreed with some existing literature on rainbow trout. ${ }^{23,17,24,18}$ In present study, no significant differences in VSI were present among fish of different dietary groups. Similar results were reported by Francesco et al. ${ }^{16}$ Palmegiano et al. ${ }^{17}$ and Jalili et al. ${ }^{18}$ Although the study period is the same as the current study, the VSI results of the present study were low from those of Jalili et al. ${ }^{18}$ who reported that may have been due to the short experimental period (60 days). However, our results were similar with those of Francesco et al. ${ }^{16}$ and Palmegiano et al. ${ }^{17}$ although the trial periods were longer than those of the present study (24 weeks and 96 days, respectively). Therefore, the VSI value could be associated with the content and effective use of the feed, not the length or shortness of the trial period.

The proximate analysis of this study indicated that moisture, lipid, protein and ash content of muscle samples were not affected by the dietary plant protein levels. In previous studies with rainbow trout and other fish species, it has been shown that the partial or total replacement of soybean meal with plant protein sources (canola meal, sunflower meal, cotton seed meal, hazelnut meal, safflower meal, DDGS (distillers dried grains with solubles) or faba beans) had no adverse effects on the body composition..$^{25-30}$

The apparent digestibility coefficient (ADC) of the in all diets were quite high (ranging from 72.38 to $77.92 \%$ ), but the ADC values in fish of $\mathrm{C}$ and $\mathrm{SP}_{10}$ groups were the highest than $\mathrm{S}_{10}$ and $\mathrm{P}_{10}$ groups. The ADC of protein in the present study were same and quite high (89.76$91.93 \%$ ), indicating efficiency of the ingredients in the experiment diets. Digestibility values in fish normally range $75-95 \%$ for protein. ${ }^{6}$ The rates in the present study were within these limits. The results of this study on the protein digestibility were similar to previous studies using other plant protein sources, e.g. with pea and canola meal, ${ }^{23}$ groundnut oil cake, soybean, mustard, sesame seed and sunflower meal, ${ }^{31}$ hazelnut meal, ${ }^{25,32}$ casava leaf meal, soybean meal, groundnut cake and sesame husk meal, ${ }^{33}$ sunflower and sesame seed meal, ${ }^{34}$ canola meal, soybean meal, DDGS, corn gluten feed, corn germ meal..$^{35}$

Consequently, results of this study showed that coexistence of sesame seed and peanut meals in rations could replace with soybean meal without any adverse effects on growth rates and feed efficiency.

\section{Acknowledgements}

We would like to thank the owner the Sibal Feed Company; Başpınar Fıstıkçılık Toprak Mah. ve Nak. Tic. Ltd. Şti, Osmaniye/ Turkey; Filiz Şekerleme Gıda Sanayi ve Tic. A.Ș., Samsun/Turkey, for supplying feedstuffs as well as the owner of the Kuzey Fish Farm Inc. for providing the experimental fish.

\section{Conflicts of interest}

None.

\section{References}

1. Yıldırım Ö, Acar Ü, Türker A, et al. Effects of replacing fish meal with peanut meal (Arachis hypogaea) on growth, feed utilization and body composition of Mozambique tilapia fries (Oreochromis mossambicus). Pakistan Journal of Zoology. 2014;46(2):497-502.

2. Tacon AGJ. Fish meal replacers: review of antinutrients within oilseed and pulses- a limiting factor for he aquafeed green revolution? In: Tacon, A., Basurca, B. (Eds.), Fish Feeding and Nutrition. Academic Press, London. 1997;pp.119-145.

3. Booth MA, Allan GL, Frances J, et al. Replacement of fish meal in diets for Australian siver perch, Bidyanus bidyanus IV. Effects of dehulling and protein concentration on digestibility of grain legumes. Aquaculture. 2001;196:67-85.

4. Siddhuraju P, Becker K. Preliminary nutritional evaluation of mucuna seedmeal (Mucuna pruriens var. utilis) in common carp (Cyprinus carpio L.): an assessment by growth performance and feed utilization. Aquaculture. 2001;196:105-123.

5. Jimoh WA, Aroyehun HT. Evaluation of cooked and mechanically defatted sesame (Sesamum indicum) seed meal as a replacer for soybean meal in the diet of African catfish (Clarias gariepinus). Turkish Journal of Fisheries and Aquatic Sciences. 2011;11:185-190.

6. NRC (National Research Council). Nutrient requirements of fish. National Academy Press, Washington D.C. 1993

7. Deguara S, Jauncey K, Feord J, et al. Growth and feed utilization of gilthead sea bream, Sparus aurata, fed diets with supplementary enzymes. CIHEAM. 1999;37:195-215.

8. El-Sayed AFM. Alternative dietary protein sources for farmed tilapia, Oreachromis spp. Aquaculture. 1999;170:149-168.

9. Brown PB. Utilization of soy products in diets of freshwater fishes. In: Alternatives Protein Sources in Aquaculture Diets Lim C, Webster CD, Lee CS (Eds.), The Howarth Press, USA. 2008;pp.225-260.

10. Kader MA, Koshio S, Ishikawa M, et al. Supplemental effects of some crude ingredients in improving nutritive values of low fishmeal diets for red sea bream, Pagrus major. Aquaculture. 2010;308:136-144.

11. Fakunle JO, Alatise SP, Effiong BN, et al. Effects of replacing Sayabeans meal with graded levels of boiles jatropha kernel meal in diets of Clarias gariepinus fingerlings. Bulletin of Environment, Pharmacology anf Life Sciences. 2013;2(9):112-117.

12. Arrieta MP, Prats-Moya MS. Free amino acids and biogenic amines in Alicante Monastrell wines. Food Chemistry. 2012;135(3):1511-1519.

13. AOAC. Official Methods of Analysis. $16^{\text {th }}$ edn. Association of Official Analytical Chemists, Arlington,VA. 1995.

14. Petry H, Rapp W. Zur problematik der chromixidbestimmung in verdauunsversuchen. Z. Tierphysiol. Tieremahrung u. Futtermittelkunde. 1970;27:181-189.

15. Degani G. Digestible energy in dietary sorghum, wheat bran and rye in common carp (Cyprinus carpio L.). Israeli J. Aquac.-Bamidgeh. 2006;58(2):71-77.

16. Francesco M, Parisi G, Médale F, et al. Effect of long-term feding with a plant protein mixture based diet on growth and body/fillet quality traits of large rainbow trout (Oncorhynchus mykiss). Aquaculture. 2004;236(1-4):413-429.

17. Palmegiano GB, Dapra F, Forneris G, et al. Rice protein concentrate meal as a potential ingredient in practical diets for rainbow trout (Oncorhynchus mykiss). Aquaculture. 2006;258:357-367.

18. Jalili R, Tukmechi A, Agh N, Replacement of dietary fish meal with plant sources in rainbow trout (Oncorhynchus mykiss); effect on growth performance, immune responses, blood indices and disease resistence. Iranian Journal of Fisheries Sciences. 2013;12(3):577-591. 
19. Olvera-Novoa MA, Olivera-Castillo L, Martinéz-Palacios CA Sunflower seed meal as a protein source in diets for Tilapia rendalli (Bounlanger, 1896) fingerlings. Aquaculture Research. 2002;33(3):223229.

20. Alarcon FJ, Moyano FJ, Diaz M. Effect of inhibitors present in protein sources on digestive proteases of juvenile sea bream (Sparus aurata). Aquatic Living Reseach. 1999;12:233-238.

21. Davies S, Fagbenro OA, Abdel-Waritho A, et al. Use of oil seeds residues as fish meal replacer in diets fed to Nile tilapia, Oreochromis niloticus. Applied Tropical Agriculture. 2000;5:1-10.

22. Datta Munshi JS, Dutta HM. Fish Morphology: Horizon of New Research. Brookfield, VT: A.A. Balkema Publishers. 1996.

23. Thiessen DL, Campbell GL, Adelizi PD. Digestibility and growth performance of juvenile rainbow trout (Oncorhynchus mykiss) fed with pea and canola products. Aquaculture Nutrition. 2003;9(2):67-75.

24. Drew MD, Ogunkoya AE, Janz DM, et al. Dietary influence of replacing fish meal and oil with canola protein concentrate and vegetable oils on growth performance, fatty acid composition and organochlorine residues in rainbow trout (Oncorhynchus mykiss). Aquaculture. 2007;267:260268

25. Bilgin Ö, Türker A, Tekinay AA. The use of hazelnut meal as a substitute for soybean meal in the diets of rainbow trout (Oncorhynchus mykiss). Turk. J. Vet. Anim. Sci. 2007;31(3):145-151.

26. Bilgüven M, Bariş M. Effects of the feeds containing different plant protein sources on growth performance and body composition of rainbow trout (Oncorhynchus mykiss, W.). Turkish Journal Of Fisheries and Aquatic Sciences. 2011;11:345-349.

27. Ustaoglu Tiril S, Kerim M. Evaluation of safflower meal as a protein sources in diets of rainbow trout (Oncorhynchus mykiss Walbaum, 1792). Journal of Applied Ichthyology. 2015;31:895-899.
28. Robinson $\mathrm{EH}, \mathrm{Li} \mathrm{MH}$. Replacement of soybean meal in cahnnel catfish, Ictalurus punctatus, diets with cottonseed meal and distiller's dried grains with solubles. Journal of the World Aquaculture Society. 2008;39(4):521-527.

29. Azaza MS, Wassim K, Mensi F, et al. Evaluation of faba beans (Vicia faba L. var. minuta) as a replacement for soybean meal in practical diets of juvenile Nile tilapia Oreochromis niloticus. Aquaculture. 2009;287:174-179.

30. Fagbenro OA, Adeparusi EO, Jimoh WA. Nutritional evaluation of sunflower and sesame seed meal in Clarias gariepinus: An assessment by growth performance and nutrient utilization. African Journal of Agricultural Research. 2010;5(22):3096-3101.

31. Mohanta KN, Mohanty SN, Jena J, et al. Effect of different oil cake sources on growth, nutrient retention and digestibility, muscle nucleic acid content, gut enzyme activities and whole-body composition in silver barb, Puntius gonionotus fingerlings. Aquaculture Research. 2007;38(16):1702-1713

32. Sevgili H, Emre Y, Kanyilmaz M, et al. Effects of replacement of fish meal with hazelnut meal on growth performance, body composition and nutrient digestibility coefficients in rainbow trout, Oncorhynchus mykiss. The Israeli Journal of Aquaculture-Bamidgeh. 2009;61(2):103-113.

33. Tram NDQ, Ngoan LD, Hung LT, et al. A comparative study on the apparent digestibility of selected feedstuffs in hybrid catfish (Clarias macrocephalus $x$ Clarias gariepinus) and Nile tilapia (Oreochromis niloticus). Aquaculture Nutrition. 2011;17(2):e636-e643.

34. Fagbenro OA, Adeparusi EO, Jimoh WA. Haematological profile of blood of African catfish (Clarias gariepinus Burchell,1822) fed sunflower and sesame meal based diets. Journal of Fisheries and Aquatic Science. 2013;8(1):80-86.

35. Li MH, Oberle DF, Lucas PM. Apparent digestibility of alternative plantprotein feedstuffs for channel catfish, Ictalurus punctatus (Rafineque). Aquaculture Research. 2013;44(2):282-288. 